\title{
Cats in Czech Rural and Urban Households
}

\author{
E. BARANYIOVÁ ${ }^{1}$, A. HOLUB, M. TYRLÍK ${ }^{2}$, M. VOLFOVÁ ${ }^{1}$ \\ ${ }^{1}$ University of Veterinary and Pharmaceutical Sciences, Brno, ${ }^{2}$ Masaryk University, Brno, Czech Republic
}

Received June 15, 2005

Accepted May 11, 2006

\begin{abstract}
Baranyiová E., A. Holub, M. Tyrlík, M. Volfová: Cats in Czech Rural and Urban Households. Acta Vet. Brno 75, 2006: 411-417.

The aim of this study was to elucidate the effects of rural and urban environments on the coexistence of humans and their cats. From the obtained questionnaire data we selected the rural cats $(\mathrm{R}, \mathrm{n}=54)$ and compared them with urban cats $(\mathrm{U}, \mathrm{n}=144)$. The $\mathrm{R}$ group cats lived predominantly in family houses, $\mathrm{U}$ cats in urban apartments.

The pressures of physical and social factors in the small niches of urban apartments (dwellings in Czech urban high-density living settings, though comfortable, are smaller than in numerous European countries; they prevailed in our U group) resulted in statistically significant differences in only $31(51.7 \%)$ out of 60 traits under study. Among them, $15(68.2 \%)$ out of 22 concerned the conduct of household members, and $16(42.1 \%)$ out of 38 concerned the behaviour of their cats. Thus the conduct of people in U households showed relatively higher proportion of changes than the behaviour of their cats. $U$ onwers more frequently purchased their cats $(R=24.1 \%, U=48.6 \%$, chi-square $=10.648, \mathrm{df}=4, p<0.05)$, they kept the cat pedigrees $(\mathrm{R}=37.0 \%, \mathrm{U}=75.4 \%$, chisquare $=24.661, \mathrm{df}=1, p<0.001)$, paid more attention to their cats $((\mathrm{R}=93.0 \%, \mathrm{U}=100.0 \%$, chi-square $=8.950, \mathrm{df}=1, p<0.005)$, talked to them daily $(\mathrm{R}=87.0 \%, \mathrm{U}=98.6 \%$, chi-square $=$ $12.024, \mathrm{df}=1, p<0.001)$, allowed them to use furniture $(\mathrm{R}=77.8 \%, \mathrm{U}=100.0 \%$, chi-square $=$ $33.839, \mathrm{df}=1, p<0.001)$, sleep in beds of family members $(\mathrm{R}=61.1 \%, \mathrm{U}=95.1 \%$, chi-square $=$ $37.149, \mathrm{df}=1, p<0.001)$, and celebrated their birthdays $(\mathrm{R}=25.9 \%, \mathrm{U}=100.0 \%$, chi-square $=$ $7.014, \mathrm{df}=2, p<0.05)$. Their cats were more destructive than $\mathrm{R}$ cats, hunted less and were less aggressive when stroked. However, they showed a slightly larger scope of aggressive behaviours and were more frequently described as nervous and restless.

The nature of the significant differences found in this study indicates that the co-existence of cats with people in the urbanized world is becoming more intimate. More interactions occur between the two species. The relationships between people and their cats deserve further study not only in order to gain more insight but also for a practical application of this knowledge.
\end{abstract}

Questionnaire, behaviour, human-cat interactions, housing,

In the information age of North America and Western Europe increasingly more cats are kept (Anon 1990; Bergler 1991; Nott 1996; APPMA 2006; Rochlitz 2000a; Voigt 2000; US Pet Ownership and Demographic Sourcebook 2002). This is also true of the Czech Republic (Turner and Bateson 2000; Mahelka 2004; Baranyiová et al. 2004b). Whereas in rural areas cats are mostly kept in family houses, in towns and cities they often live in relatively small apartments. This affects their interactions with household members. The human-cat bond may be stronger or weaker, depending on the roles that cats play in the household activities. For example, in rural areas they are expected to protect the household from rodents whereas in towns and cities they are perceived as companions and share permanently the apartment niches with their owners (Baranyiová et al. 2004b).

More detailed knowledge of the consequences of human and cat co-existence under these two different conditions is still rather fragmentary and modest (Bergler 1988, 1991; Turner 1991, 1995, 2000; Beaver 1992; Houpt 1998; Turner and Rieger 2001; Baranyiová et al. 2004b; Rochlitz 2005). We therefore decided to further explore and elucidate this bond.

Address for correspondence:

Doc. MVDr. E va Baranyiová, CSc.

University of Veterinary and Pharmaceutical Sciences

Palackého 1-3, 61242 Brno

Czech Republic
Phone: +420 541562791

E-mail: actavet@vfu.cz

http://www.vfu.cz/acta-vet/actavet.htm 


\section{Materials and Methods}

We analysed data obtained by a questionnaire based on Askew (1997) and Bergler (1991) published in the monthly magazine "Naše kočky" (Our Cats). Its readers provided about $90 \%$ of the data. The rest was obtained from clients of veterinary practices who were contacted personally (Baranyiová et al. 2004b). We thus evaluated the behaviour of 198 cats whose owners provided information about their housing type. Group 1 comprised 54 cats living in rural areas (R), group 2 was formed of 144 cats living in urban settings (U).

The questionnaire had 60 questions that were in part binary, in part multiple. They can be summarized into several groups:

a) data on age, sex and breed of the cat, age at acquisition and health status,

b) data on the structure of the household (number of adults and children, species and numbers of other animals), housing style,

c) the daily regime of cats (including their nutrition),

d) other behaviours of cats, including the negatively perceived ones such as aggression,

e) evaluation of the overall position of cats in the households.

We were mainly interested in how frequently the behaviours were observed and whether there were significant differences between rural and urban cats. Per cent proportions were calculated from the actual numbers of owner answers and not from the frequencies of groups. Analysis of contingency tables was carried out using $\chi^{2}$ test (statistical software SPSS v. 8).

\section{Results}

In both groups, $\mathrm{R}$ and $\mathrm{U}$, we compared 60 traits, behaviours of cats and conduct of their owners.

The compared groups did not differ significantly in numbers of household members except for the fact that in group $\mathrm{R}$ no one-member household was reported $(\mathrm{R}=0.0 \%, \mathrm{U}=25.2 \%$, $\chi^{2}=10.114, \mathrm{df}=2, p<0.01$ ), whereas in group $\mathrm{U}$ these households comprised one fifth. Moreover, they consisted exclusively of women. In $\mathrm{R}$ areas, also other animals were kept more frequently with cats $(\mathrm{R}=15.1 \%, \mathrm{U}=4.3 \%$, n.s. $)$, and $\operatorname{dogs}\left(\mathrm{R}=34.0 \%, \mathrm{U}=17.3 \%, \chi^{2}\right.$ $=16.230, \mathrm{df}=3, p<0.001)$. U cats thus lived in a less complex social environment.

We evaluated 22 conduct traits of household members. Their responses indicate that sex distribution of cats in $\mathrm{R}$ and $\mathrm{U}$ groups did not differ significantly: the proportion of tomcats $(\mathrm{R}=26.4 \%, \mathrm{U}=17.8 \%)$, female cats $(\mathrm{R}=41.5 \%$. $\mathrm{U}=45.9 \%)$ or neutered animals $(\mathrm{R}=$ $32.2 \%, \mathrm{U}=36.2 \%)$. Similarly, kittens did not differ in age at which they were adopted into $\mathrm{R}$ or $\mathrm{U}$ households. Most of them were adopted before 10 weeks of age $(\mathrm{R}=59.3 \%, \mathrm{U}=$ $46.3 \%)$, fewer before they reached six months $(\mathrm{R}=27.8 \%, \mathrm{U}=44.1 \%)$ and only the rest of them at an older age $(\mathrm{R}=13.0 \%, \mathrm{U}=9.6 \%)$. We found a significant association between the type of housing and the way in which the cat was acquired. In rural areas only one fourth of cats were purchased whereas in urban areas is was nearly a half of them $(\mathrm{R}=24.1 \%, \mathrm{U}=$ $\left.48.6 \%, \chi^{2}=10.648, \mathrm{df}=4, p<0.05\right)$. In the $\mathrm{R}$ environment significantly fewer people cared for the origin of their cats. Only about one third of these animals were pedigree cats whereas in urban areas three quarters of cats were purebreds with a pedigree $(\mathrm{R}=37.0 \%, \mathrm{U}=75.4 \%$, $\left.\chi^{2}=24.661, \mathrm{df}=1, p<0.001\right)$. A significant association was found between the age and morbidity of $\mathrm{R}$ and $\mathrm{U}$ cats. Up to the age of six months, rural cats were sick more frequently $(\mathrm{R}=28.6 \%, \mathrm{U}=3.8 \%)$; whereas urban cats suffering from diseases were three and more years of age $\left(\mathrm{R}=19.0 \%, \mathrm{U}=46.2 \%, \chi^{2}=7.289\right.$, $\left.\mathrm{df}=2, p<0.05\right)$.

Cat owners reported that more than four fifths of cats in both groups had toys and scratching posts $(\mathrm{R}=83.3 \%, \mathrm{U}=89.1 \%)$. There were no differences in frequency and length of time that the household members spent playing with their cats $(\mathrm{R}=83.3 \%, \mathrm{U}=94.4 \%)$.

When analyzing 38 traits of cat behaviour we found no differences except for one case of feeding behaviour; $\mathrm{R}$ cats were hunting more frequently $\left(\mathrm{R}=16.7 \%, \mathrm{U}=2.1 \%, \chi^{2}=113\right.$. $978, \mathrm{df}=8, p<0.001)$. Both groups equally soiled the living quarters, defecated $(\mathrm{R}=7.4 \%$, $\mathrm{U}=5.8 \%)$, urinated $(3.7 \%, \mathrm{U}=6.3 \%)$ and urine-marked $(\mathrm{R}=1.9 \%, \mathrm{U}=1.4 \%)$. In urban cats, though rarely, pathological behaviours were reported such as excessive nibbling/biting and licking of haircoat $(\mathrm{R}=0.0 \%, \mathrm{U}=0.7 \%)$ and insufficient grooming 
$(\mathrm{R}=0.0 \%, \mathrm{U}=0.7 \%)$, whereas in $\mathrm{R}$ cats these behaviours were not found at all. Urban owners complained significantly more often than the rural ones about their cats scratching furniture and carpets $\left(\mathrm{R}=56 \%, \mathrm{U}=25.2 \%, \chi^{2}=9.503, \mathrm{df}=1, p<0001\right)$.

Analysis of feline aggression indicated that cats of the two groups did not differ in their interspecies aggression $(\mathrm{R}=18.5 \%, \mathrm{U}=11.9 \%$, n.s.). Rural cats were more frequently aggresssive when petted $\left(\mathrm{R}=5.6 \%, \mathrm{U}=0.7 \%, \chi^{2}=4.647, \mathrm{df}=1, p<0.05\right)$, but they showed no aggression at all when punished or reached toward, and were not aggressive to unknown persons or household children (all $\mathrm{R}=0.0 \%, \mathrm{U}=0.7 \%$ ).

The respondents made conclusions about the character and nature of their $\mathrm{U}$ and $\mathrm{R}$ cats. More than nine tenths of cats were described as able to perceive the moods of household members $(\mathrm{R}=90.7 \%, \mathrm{U}=96.5 \%)$, four fifths of them were considered cuddly $(\mathrm{R}=81.5 \%$, $\mathrm{U}=81.8 \%)$ and about two thirds of them were described as playful $(\mathrm{R}=63.0 \%, \mathrm{U}=70.6 \%)$. About one half of the cats were considered independent $(\mathrm{R}=51.9 \%, \mathrm{U}=42.7 \%)$. Other traits were found rarely. For example, excessive locomotor activity $(\mathrm{R}=16.7 \%, \mathrm{U}=11.9 \%)$ or hypoactivity $(\mathrm{R}=9.3 \%, \mathrm{U}=7.7 \%)$ was reported in both groups only in about one tenth of the cats. In the $\mathrm{R}$ group, not a single cat was described as nervous or restless.

On the other hand, in data on the position of cats in households significant differences were found more often. In $\mathrm{U}$ households they were given more attention $(\mathrm{R}=93.0 \%, \mathrm{U}=$ $\left.100.0 \%, \chi^{2}=8.950, \mathrm{df}=1, p<0.005\right)$, household members spoke to their cats $(\mathrm{R}=87.0 \%$, $\left.\mathrm{U}=98.6 \%, \chi^{2}=12.024, \mathrm{df}=1, p<0.001\right)$, tolerated their use of furniture $(\mathrm{R}=77.8 \%, \mathrm{U}=$ $\left.100.0 \%, \chi^{2}=33.839, \mathrm{df}=1, p<0.001\right)$, sleeping in beds of family members $(\mathrm{R}=61.1 \%$, $\mathrm{U}=95.1 \%, \chi^{2}=37.149$, df $\left.=1, p<0.001\right)$, and they celebrated the cats' birthdays $\left(\mathrm{R}=25.9 \%, \mathrm{U}=100.0 \% \chi^{2}=7.014, \mathrm{df}=2, p<0.05\right)$.

When the expected and observed frequencies in the individual fields of the contingency tables were compared, we found statistically significant differences in about one half of the traits under study, i.e. in 31 out of $60(51.7 \%)$. The physical and social pressures in the small niches of urban apartments manifested themselves significantly. They were more frequently found in the conduct and actions of household members - in 15 (68.2\%) out of 22 cases, i.e. in two thirds of traits. In the evaluation of cat behaviour this was true in 16 $(42.1 \%)$ out of 38 cases, i.e. in two fifths of traits. In the activities of urban household members we thus found relatively more changes (by 1/4) than in the behaviour of their cats.

\section{Discussion}

Urbanization of the Czech society has several specific features. For example, high-density living settings making up a large proportion of urban dwellings, may be technically well equipped and comfortable for people, yet they are smaller than those in other European countries (Baranyiová et al. 2005). Moreover, in these small urban niches indoor cats are kept for long periods, often for a whole lifetime. These physical factors impose an inevitable strong pressure on them.

Cats are exposed to other, social influences, too: for example, urban households in our study were also one-person households and consisted exclusively of women. Hence women seem to select cats for their companions more frequently. It is generally assumed that the cat-human relationship is more intense, when the human partner is female (Turner et al. 2003; Adamelli et al. 2005). Cats themselves contribute to the closeness of this bond. This is perhaps because usually women take care of the cats, and feed them (Bradshaw 1992). Nevertheless, this problem has not been sufficiently elucidated and the opinion of Adamelli et al. (2005) can be supported that it needs further investigation in order to clarify whether women are really more involved in interactions with cats than men. Apart from this, in our U households there were fewer other animals kept. Thus cats living in these households had fewer social interactions. 
These unusual and unprecedented physical and social pressures in $U$ households significantly affected only a few (two fifths) of the feline behaviour traits under study (Baranyiová et al. 2003ab, 2004ab). Cats show less exploratory activity, they leave the apartments less frequently, roam less and hunt rarely. They tolerate better unsolicited physical contact and stroking. However, they are more often described as nervous and restless. This fact may be the result of lack of physical activity, since rural cats may have territories as large as 200 (females) and 600 hectares (males), as reported by Turner and B ate son (1988, cited in Houpt 1998). In our U cats, grooming tended to be either excessive or neglected. They also showed several types of aggression not encountered in $\mathrm{R}$ cats.

They significantly more often scratched furniture and carpets, soiled the apartment though not as frequently as reported in Great Britain where house soiling (indoor marking) is considered as the most frequent problem reported by cat owners, making up $25 \%$ of the problems seen (Anon 2002; Hoole 2004).

Interestingly, the cat owners' conduct was changed more than the behaviour of pet cats in U households. We found a similar trend in households with dogs (B aranyiová et al. 2005). Human-cat interactions in $U$ and $R$ conditions differed significantly in two thirds of the indicators under study. When selecting their cats, urban people act differently than rural owners: they more often purchase the cats, keep their pedigree, pay more attention to them, talk to them daily, allow them to use furniture and sleep in beds. They celebrate the cats' birthdays and, generally, show a higher degree of attachment to them.

In recent decades, these problems, namely the effects of various physical and social variables on the behaviour of cats are given more attention from multiple approaches. However, the data are often based only on surveys of their housing in laboratories, quarantine stations and shelters (McCune 1995; Rochlitz et al. 1998; Ottaway and Hawkins 2003; Rochlitz 2005). They are sometimes connected with the "The Five Freedoms" of the Brambell report (1965), with the attempts to enrich their environment and improve welfare (Turner 1995; Scott et al. 2000; Young 2003) and the aim of preventing behavioural problems (Schroll 2002). Fewer are directly aimed at interactions of humans and cats in households (Mertens and Turner 1988; Mertens 1991; Rochlitz 2005) and on problems of outdoor and indoor housing. Most authors agree that cats adapt well to life in urbanized environment, especially when they are raised indoors from an early age (Rochlitz 2005). Our observations also demonstrate great adaptability of cats living in urban environments as evidenced by the frequency of some of their behavioural traits being significantly different from those of the rural cats. However, cats that began to live in small urban apartments later in their lives, at an older age, may have some behavioural problems (Hubrecht and Turner 1998).

Some authors draw attention to differences between outdoor and indoor cats in conditions and risks of disease (B uffington 2002). This fact may be connected with our findings on significant differences in age distribution of morbidity between $\mathrm{R}$ and $\mathrm{U}$ cats; $\mathrm{R}$ cats tended to be more frequently sick before 6 months of age whereas more $U$ cats when sick, were older than 3 years.

It is necessary to note that the respondents to our questionnaire represent that portion of Czech population that has a positive attitude to cats. They are interested in their cats, observe them carefully, and are able to formulate their views about the behaviour of the cats. Some of them read regularly cat magazines, participate in internet chats about cats and seek professional help when necessary. Therefore they cannot be considered as fully representative of the human population of the country. Also in the Czech Republic the views about keeping cats are somewhat polarised and controversial (B aran yiová et al. 2003ab, $2004 \mathrm{ab})$. It may be assumed that some portion of the population does not like cats.

Domestication of cats may be interpreted as a process that began in the Middle East 
thousands of years ago by mutual approach of the two species when crop protection from rodents became a necessity. Cats were able to retain their relative independence from people. Their domestication, however, may be seen in a different way. They began to lay and rest near stoves and purr in their owners' laps much later, and only recently they have been given the chance to enjoy the comfort of our urbanized homes. Therefore they are sometimes considered as domesticated as late as during the last 150 years (Bökön yi 1989; Serpell 2000). Their domestication continues presently, in different ways in differring environments. Their behaviour continues to show obvious signs of independence and selfreliance, and their locomotor behaviours are highly variable. They have many specific individual features and differ from other types of human-animal interaction ( $\mathrm{Bradshaw}$ 1992). It makes the interpretation of their behaviour more difficult. Therefore exact observations of feline locomotion are difficult to interpret and generalize.

Moreover, cats continue to be encompassed with controversial tales, myths and prejudices, by their opponents and lovers alike. They are considered to be independent, unpredictable, false, but also charming, cuddly, reserved and shy. It is possible that such anthropomorphism makes itself felt also in the views of our respondents. More thorough knowledge and objective understanding and interpretation of feline behaviour and their relationships to humans need further efforts (B aranyiová et al. 2004b).

\section{Kočky v českých venkovských a městských domácnostech}

Ve snaze zjistit, jak se vliv venkovského a městského prostředí uplatňuje v soužití lidí a koček v českých domácnostech, oddělili jsme ze souboru koček, kterým se opakovaně zabýváme, kočky městské $(\mathrm{U}, \mathrm{n}=144)$ a srovnávali je s venkovskými $(\mathrm{R}, \mathrm{n}=54)$. Skupina $\mathrm{R}$ žila převážně v rodinných domcích se zahradou, skupina U v městských bytech. Data jsme získávali pomocí dotazníků.

Fyzikální a sociální tlak urbanizovaného prostředí, malých nik městských bytů (české sídlištní byty, které v městské skupině převažují, jsou sice komfortní, ale mají menší plochu než v četných zemích Evropy), vyvolávají statisticky významné rozdíly jen u 31 (51,7\%) ze 60 sledovaných znaků. Z toho jich $15(68,2 \%)$ ze 22 připadá na jednání členů domácností a $16(42,1 \%)$ ze 38 na chování koček. Jednání lidí v U domácnostech tudíž vykazuje relativně větší počet změn než chování jejich koček. Městští chovatelé si kočky průkazně častěji kupují polovina $\left(\mathrm{R}=24,1 \%, \mathrm{U}=48,6 \%, \chi^{2}=10,648, \mathrm{df}=4, p<0,05\right)$, mají doklady o jejich původu $\left(\mathrm{R}=37,0 \%, \mathrm{U}=75,4 \%, \chi^{2}=24,661, \mathrm{df}=1, p<0,001\right)$, nechovají doma další živé tvory, více si svých koček všímají $\left(\mathrm{R}=93,0 \%, \mathrm{U}=100,0 \%, \chi^{2}=8,950, \mathrm{df}=1\right.$, $p<0,005)$, častěji na ně mluví $\left(\mathrm{R}=87,0 \%, \mathrm{U}=98,6 \%, \chi^{2}=12,024, \mathrm{df}=1, p<0,001\right)$, slaví jejich narozeniny $\left(\mathrm{R}=25,9 \%, \mathrm{U}=100,0 \% \chi^{2}=7,014, \mathrm{df}=2, \mathrm{p}<0,05\right)$, dovolují jim využívat bytové vybavení zařízení $\left(\mathrm{R}=77,8 \%, \mathrm{U}=100,0 \%, \chi^{2}=33,839, \mathrm{df}=1, p<0,001\right)$ a spát $\mathrm{v}$ postelích postelích $\left(\mathrm{R}=61,1 \%, \mathrm{U}=95,1 \%, \chi^{2}=37,149, \mathrm{df}=1, p<0,001\right)$. Jejich kočky více destruují zařízení domácností, škrábou po nábytku a kobercích, méně loví a bývají méně agresivní při hlazení. Vykazují však širší, byt nevelké, spektrum agrese a bývají označovány za nervózní a neklidné.

Povaha průkazných odchylek vesměs dokládá, že soužití koček s lidmi je v urbanizovaném světě těsnější. Interakcí lidí a koček přibývá. Kočky své malé zatěžující niky téměř neopouštějí a mimo ně jeví menší explorativní aktivitu. Zkoumání vztahủ lidí a koček v urbanizovaném světě je žádoucí v zájmu jejich hlubšího poznání i praktického využití zintenzivňovat.

\section{Acknowledgements}

The study was partly supported by the MŠMT projects FRVŠ 1471/2004 and 1823/2005. 


\section{References}

ADAMELLI S, MARINELLI L, NORMANDO S, BONO G 2005: Owner and cat features influence the quality of life of the cat. Appl Anim Behav Sci 94: 89-98

Anonymous 1990: Cats across the world. Anthrozoös 3: 196

Anonymous 2002: Behavioural problems in cats and dogs. Vet Rec 151: 252

APPMA: 2005-2006 National Pet Owners Survey. American Pet Product Manufacturers Association Inc. Greenwich 2006. LXIII and $376 \mathrm{p}$.

ASKEW HR: Behandlung von Verhaltensproblemen bei Hund und Katze. Paul Parey, Berlin 1997. VII a 372 p.

BARANYIOVÁ E, HOLUB A, JANÁČKOVÁ B, ERNSTOVÁ M 2001: Výpovědi chovatelů o psech v České republice. Veterinářství 51: 167-171

BARANYIOVÁ A, HOLUB A, VOLFOVÁ M, TYRLÍK M, LIČKOVÁ A, SAMKOVÁ A 2003a: Psi a kočky v českých domácnostech - srovnání. (Dogs and cats in Czech households - a comparison) In: 30. etologická konference. Program a abstrakta. Jičín. p. 42

BARANYIOVÁ A, HOLUB A, VOLFOVÁ M, TYRLÍK M, LIČKOVÁ A, SAMKOVÁ T 2003b: Psi a kočky v českých domácnostech. (Dogs and cats in Czech households). In: Ochrana zvířat a welfare 2003, část A. Brno. p. $8-12$

BARANYIOVÁ A, HOLUB A, VOLFOVÁ M, TYRLÍK M, LIČKOVÁ A, SAMKOVÁ T 2004a: Kočky v našich domácnostech. (Cats in our households). In: 31. etologická konference. Program a abstrakta. Polana. p. 43

BARANYIOVÁ E, HOLUB A, VOLFOVÁ M, TYRLIK M, LIČKOVÁ A, SAMKOVÁ A 2004b: Výpovědi respondentů o kočkách v České republice. (Responses of owners about cats in the Czech Republic). Veterinářství 54: 490-496

BARANYIOVÁ E, HOLUB A, TYRLÍK M, JANÁČKOVÁ B, ERNSTOVÁ M 2005: The influence of urbanization on the behaviour of dogs in the Czech Republic. Acta vet Brno 74: 401-409

BEAVER BV 1992: Feline Behavior: A Guide for Veterinarians. W.B. Saunders, Philadelphia, 276 p.

BEAVER BV 2002: Behavioural problems in cats and dogs. Vet Rec 151: 252

BERGLER R 1988: Die Psychologie der Beziehungen von Heimtieren, Heimhalter und Tierärzten. J Vet Med B 35: 443-461

BERGLER R 1991: Man and Cat. Blackwell Scientific Publications. London. 120 p.

BÖKÖNYI S 1989: Definition of animal domestication. In: The Walking Larder: patterns of domestication, pastoralism, and predation. London p. 22-27

BRADSHAW JWS 1992: The cat-human relationship. In: The Behaviour of the Domestic Cat. Wallington, UK, CAB International, p. 163-176

BRAMBELL FWR 1965. Report of the Technical Committee to Enquire into the Welfare of Livestock Kept Under Intensive Husbandry Systems. London

BUFFINGTON CAT 2002: External and internal influences on disease risk in cats. J AmerVet Med Assoc 220: 994-1002

HOOLE J 2004: Annual Review of Cases 2003., accessed May 21, 2004

HOUPT KA 1998: Domestic Animal Behavior for Veterinarians and Animal Scientists. Third edition. Iowa State University, Ames. 495 p.

HUBRECHT RC, TURNER DC 1998: Companion animal welfare in private and institutional settings. In: Companion Animals and Human Health. Thousand Oaks. p. 267-289

MAHELKA B 2004: Personal communication

MCCUNE S 1995: Enriching the environment of the laboratory cat - a review. In: Proceedings of the Second International Conference on Environmental Enrichment. Copenhagen. pp. 103-117

MERTENS C 1991: Human-cat interactions in the human setting. Anthrozoös 4: 214-231

MERTENS C, TURNER DC 1988: Experimental analysis of human-cat interaction during first encounters. Anthrozoös 2: 83-97

NOTT HMR 1996: Eurocats. J Feline Advis Bureau 34: 46-47

OTTWAY DS, HAWKINS DM 2003: Cat housing rescue shelters: a welfare comparison between communal and discrete-unit housing. Anim Welfare 12: 173-189

ROCHLITZ I 2000a: Feline welfare issues. In: TURNER DC, BATESON P (Eds): The Domestic Cat. The biology of its behaviour. Second edition. Cambridge University Press, Cambridge, pp. 207-226

ROCHLITZ I 2000: Recommendations for the housing and care of domestic cats in laboratories. Lab Animals 34: $1-9$

ROCHLITZ I 2005: A review of the housing requirements of domestic cats (Felis silvestris catus) kept in the home. Appl Anim Behav Sci 93: 97-109

ROCHLITZ I, PODBERSCEK AL, BROOM DM 1998: The welfare of cats in a quarantine cattery. Vet Rec 143: 35-39

SCHROLL S: Environmental enrichment for indoor cats as prevention and therapy-practice advise for quality of life. In: Proceedings of the Companion Animal Behaviour Therapy Study Group. Birmingham 2002. p. 43-45

SCOTT PW, STEVENSON MF, COOPER JE, COOPER ME: Secretary of State\#s Standards of Modern Zoo Practice. Norwich 2000 
SERPELL JA: Domestication and history of the cat. In: TURNER DC, BATESON P (Eds): The Domestic Cat. The biology of its behaviour. Second edition. Cambridge University Press, Cambridge 2000. p. 179-192

TURNER DC, BATESON P 1988: The Domestic Cat. The Biology of Its Behaviour. Cambridge University Press TURNER DC 1991: The ethology of the human-cat relationship. Schw Arch Tierheilk 133: 63-70

TURNER DC 1995: Ethologie und Wohlbefinden bei Heimtieren. Schw Arch Tierheilk 137: 45-49

TURNER DC 2000: The human-cat relationship. In: TURNER DC, BATESON P (Eds): The Domestic Cat. The biology of its behaviour. Second edition. Cambridge University Press, Cambridge, pp. 193-206

TURNER DC, BATESON P 2000: Why the cat? In: TURNER DC, BATESON P (Eds): The Domestic Cat. The biology of its behaviour. Second edition. Cambridge University Press, Cambridge, pp. 3-6

TURNER DC, RIEGER G 2001: Singly living people and their cats: A study of human mood and subsequent behavior. Anthrozoös 14: 38-46

TURNER DC, RIEGER G, GYGAX L 2003: Spouses and cats and their effects on human mood: Anthrozoös 16: 213-228

U. S. Pet Ownership \& Demographics Sourcebook. Schaumburg 2002. 46 p.

VOIGT A: 2000 AVMA Directory and Resource Manual. AVMA, Schaumburg 2000. 1022 p.

YOUNG RJ: Environmental Enrichment for Captive Animals. Oxford 2003 
